\title{
Clinical usage of amino acids
}

By R. G. Clark, W. G. Lambert, D. Mangnall, H. F. Woods and G. H. Tucker, University Surgical Unit, Northern General Hospital, Department of Therapeutics, University of Sheffield, Sheffield $S_{5} 7 A U$

Maintenance of body homoeostasis is the objective of metabolic management of the critically ill patient. For some time now interest has shifted beyond the control of the volume and function of the extracellular fluids (ECF) to more fundamental aspects of the metabolic changes associated with malnutrition and acute disease in the intracellular phase, and the influence which nutrient administration has on them. A great deal of interest has developed in protein metabolism in clinical nutrition and much of this is related to the parenteral administration of amino acid solutions, i.e. infusion of solutions with different amino acid profiles with or without energy. The requirement for amino acids varies between different disease states (Kinney, I980) but the exact needs cannot always be accurately defined, nor is it exactly clear what the appropriate energy is for any given amino acid requirement in many of these states. Much information is now available on methods of estimation of requirements and on the clinical benefits of nutritional support (Mullen et al. 1980) and there is a growing volume of information on the changes in amino acid patterns associated with disease (Askanazi, Carpentier et al. 1980; Askanazi, Fürst et al. 1980; Fürst et al. 1982) in plasma and in muscle. However, we are not yet certain how the clinical effect of improved nutrition is mediated or whether alteration of the amino acid profile of a solution can restore these patterns to the accepted normal state, nor is it known whether this confers any benefit to the patient. These gaps in our knowledge are being filled fairly rapidly and the advent of isotope turnover studies, improved techniques for amino acid analysis and for tissue analysis to augment the more traditional nitrogen balance studies have been of great importance. This presentation will look at some aspects of amino acid and protein metabolism with particular reference to what the parenteral use of amino acids can achieve in clinical practice and which objectives the clinician should be aiming for.

\section{Response to amino acid turnover}

Within $2 \mathrm{~h}$ of the start of an amino acid infusion a new steady-state is reached for all the substrates being infused (Abumrad et al. 1982). The final plasma concentration of each amino acid will depend on its concentration in the infusate, the rate of administration, the rate at which it is cleared from the circulation, the nutritional and metabolic status of the patient and the energy available to promote utilization. In recent years, work on the pharmacokinetics of amino acids after a short infusion of either single or mixed amino acid solutions has shown that most 
amino acids have a relatively short half-life of less than $30 \mathrm{~min}$ and a clearance of less than $15 \mathrm{ml} / \mathrm{kg}$ per min (Burger et al. 1978; Elia et al. 1980; Mosebache et al. 1980; Kingsland et al. I981). There are, however, wide discrepancies. Some, asparate, glutamate and glycine, have a relatively short half-life and all the infused substrate will be eliminated from the circulation within $40-60 \mathrm{~min}$ (W. G. Lambert, D. Mangnall, R. G. Clark, H. F. Woods and G. T. Tucker, unpublished results). The remainder take much longer to clear completely and, for example, in the case of valine and tyrosine, their concentration may still be elevated substantially above basal values at $60 \mathrm{~min}$ after infusion has ceased. These variations between amino acids indicate that analysis on a compartmental basis may not be accurate and other methods of analysis will be required to provide comparative results.

It is not possible to compare directly the effect of an intravenous infusion of amino acids with a protein meal. However, the study by Abumrad et al. (1982) of amino acid balance across the forearm during the infusion of the amino acid solution Freamine II would not suggest major differences. During the basal period before infusion there was a significant release of $\alpha$-amino $\mathrm{N}$ of $300 \mathrm{nmol} / \mathrm{ro0} \mathrm{g}$ muscle per min with alanine and glutamine accounting for $80 \%$ of the efflux with the branched-chain amino acids (BCAA) accounting for $10 \%$. Infusion of the Freamine II induced a reversal of amino acid balance across the forearm with a net uptake of $\alpha$-amino $\mathrm{N}$ of $1200 \mathrm{nmol} / 100 \mathrm{~g}$ muscle per min, with the BCAA accounting for $50 \%$ of the uptake. The combined release of alanine and glutamine did not change but the glutamine output increased by $50 \%$ while the alanine output decreased by $40 \%$. However, the fate of those amino acids extracted by skeletal muscle, especially the BCAA, remains unclear. The evidence from this study points to their retention in a free intracellular amino acid pool which serves as a reservoir for the infused amino acids for a number of hours. However, although studies such as this demonstrate effective utilization of intravenouslyinfused amino acids, the results raise other questions. Only $50 \%$ of the administered load of BCAA seems to be taken up by skeletal muscle and it is suggested that other tissues are as important in the handling of these amino acids.

Injury and sepsis are characterized by changes in the amino acid profile in plasma and muscle. Minor variations are reported in the pattern from centre to centre but there is general agreement (Vinnars et al. 1975; Askanazi, Carpentier et al. 1980; Askanazi, Fürst et al. 1980; Roth et al. 1982) that following injury and sepsis there is an elevation in the muscle and the plasma of the BCAA and of phenylalanine, tyrosine, methionine and glycine. There is a marked decrease in muscle glutamine and smaller decreases in the basic amino acids lysine, histidine and arginine in muscle and, to a lesser extent, in plasma. The same amino acid distribution is found in many clinical states and this has suggested to one of these groups (Askanazi, Carpentier et al. 1980; Askanazi, Fürst et al. 1980) that the response is almost an 'all or none' phenomenon which may be the result of alteration in the control of amino acid transport in the muscle cell. It is of great interest that this abnormal intracellular amino acid pattern is not affected by nutritional support 
over a wide range of protein and energy intakes (Askanazi, Carpentier et al. 1980; Askanazi, Fürst et al. 1980; Vinnars et al. 1983) and recovery of the normal distribution of amino acids seems to depend on the return of the anabolic phase of convalescence.

\section{Energy requirement for optimum utilization of amino acid solutions}

The wide range of parenteral nutrition solutions now available for administration of amino acids $(4 \cdot 3-17.0 \mathrm{~g} \mathrm{~N} / \mathrm{l})$, carbohydrates $(5-50 \%)$ and fats $(10-20 \%)$ provides a variety of regimens ranging from those containing amino acids with little or no exogenous energy (Blackburn et al. 1973; Miller et al. 1983), often called 'hypocaloric feeding' or 'protein sparing', to intakes of two or three times the normal energy requirements (Reilly et al. 1976). Such a variety of approaches to nutritional support is indicative of the spectrum of metabolic states associated with serious disease. Thus, there is some confusion in thought about the objectives of nutritional support and the best means of achieving these. The principal objective is to restore or sustain homoeostasis by preserving and maintaining the function of the body cell mass: this requires the use of amino acid solutions with the optimum quantity of exogenous energy which will obtain the maximal effect. A better understanding of the circumstances which will attain this goal is of importance both to the pharmaceutical industry, which produces the solutions for infusion, and the nutrition teams, which have to prescribe the needs.

$\mathrm{N}$ metabolism is highly sensitive to variations in intakes of both protein and energy. The range of requirements will vary from $0.16 \mathrm{~g} \mathrm{~N} / \mathrm{kg}$ per $\mathrm{d}$ in the depleted and normally nourished state to $0.35^{-0} .4^{\circ} \mathrm{g} \mathrm{N} / \mathrm{kg}$ per $\mathrm{d}$ in the severely catabolic patient such as that with major burns injury. It has been customary to estimate the energy requirements necessary by adopting a rule-of-thumb measure relating the amount of energy to the amount of $\mathrm{N}$ to be given. The most widely adopted ratio $(\mathrm{kJ}: \mathrm{g} \mathrm{N}(\mathrm{kcal}: \mathrm{g} \mathrm{N})$ ) is $834: \mathrm{I}(200: \mathrm{I})$ (Moore, 1959) which was based on the ratio found in the average oral diet. Bozzetti et al. ( $\mathrm{I} 980$ ) found that the optimum ratio to achieve weight gain in a series of undernourished patients with malignant disease was 867:I (208:I), Peters (1980) found the ratio of $679: 1$ ( $163: 1$ ) to be the most efficacious for $\mathrm{N}$ equilibrium in patients with inflammatory bowel disease and Long et al. (1976) suggested a ratio of 750:1 (180:I) in a detailed study of acutely ill patients with sepsis. Most of the work on energy requirements has used the $\mathrm{N}$ balance technique to assess efficacy, and some part of the difference between these ratios may be accounted for by differences in the design of the study, but more than one factor is involved in the response of body $\mathrm{N}$ balance to changes in nutrient intake. The depleted patient responds in a manner quite different to the normally nourished and catabolic patient so that the nutritional and metabolic status of the patient must be of paramount importance. The normally or well nourished individual will retain additional protein if the $\mathrm{N}$ intake is increased above requirements for zero $\mathrm{N}$ balance and will lose protein if the intake is lowered below that level; the effect lasts for about $10 \mathrm{~d}$ after which a new steady-state is established (Munro, 1964). The depleted patient differs from the normal in being 
able to achieve positive $\mathrm{N}$ balance at zero energy balance for a sustained period of time and thus resembles the growing child (Elwyn, 1980). The injured or septic patient on the other hand is unlikely to reach $\mathrm{N}$ equilibrium at zero energy balance. Other factors of importance include the quality and the composition of the amino acid solution being used (Long et al. 1976) and the need for all other essential nutrients to be administered concomitantly.

The major determinant of the effect of amino acid intake must be the balance between intake and requirement of both protein and energy. Calloway \& Spector (1954) have defined the basis of this relationship in a composite summary of data from a number of studies in young men. Provided that energy intake is adequate, increasing the $\mathrm{N}$ intake improves $\mathrm{N}$ balance but when energy intake is limited the effect of increasing $\mathrm{N}$ intake disappears. The effect of increasing energy intake is similar and, provided that the $\mathrm{N}$ intake is not limited, $\mathrm{N}$ balance remains positive as the energy intake is increased. The response is not a linear one but, as Peters ( 1980 ) has also shown in studies of depleted patients with inflammatory bowel disease, is curvilinear with a steep slope at the lower levels of intake $(1.0-5.0 \mathrm{~g}$ $\mathrm{N} / \mathrm{d}$ ) representing a rate of increase of approximately $20-30 \mathrm{mg} \mathrm{N} / \mathrm{kJ}(5-7 \mathrm{mg}$ $\mathrm{N} / \mathrm{kcal})$ and a smaller rate of increase of $4-20 \mathrm{mg} \mathrm{N} / \mathrm{kJ}(\mathrm{I}-5 \mathrm{mg} \mathrm{N} / \mathrm{kcal})$ at the higher intakes $(7.0-1 \mathrm{I} \circ \mathrm{g} \mathrm{N} / \mathrm{d})$. Clinical studies have tended to demonstrate that these relationships also operate in the seriously depleted patient who is not hypermetabolic or hypercatabolic. In a study of severely depleted patients with a mean weight loss of $27 \%$ given three levels of energy intake $\left(64.2,{ }_{5} 6 \cdot 7\right.$ and 243.8 $\mathrm{kJ} / \mathrm{kg}$ per d ( $15.4,37.6$ and $58.5 \mathrm{kcal} / \mathrm{kg}$ per d)) with a constant intake of protein (0.17 g N/kg per d), Elwyn et al. (1979) found a consistent improvement in $\mathrm{N}$ balance of $7.1 \mathrm{mg} \mathrm{N} / \mathrm{kJ} \mathrm{(1.7} \mathrm{mg} \mathrm{N/kcal)} \mathrm{with} \mathrm{increasing} \mathrm{energy} \mathrm{intake,} \mathrm{a} \mathrm{value}$ similar to that found in normal adults. By the use of indirect calorimetric measurement of energy expenditure these authors have explained why the depleted patient appears to have a greater efficiency of utilization of $\mathrm{N}$. The same incremental rate of $\mathrm{N}$ retention is found in the depleted as in the normal individual but the intercept changes so that $\mathrm{N}$ equilibrium is achieved at a lower energy intake. This shift is achieved by the reduction in energy expenditure of the depleted patients.

The injured or septic patient has an abnormal metabolic environment, often described as hypercatabolic, which is characterized by an increase in $\mathrm{N}$ excretion well above the normal range and an associated negative $\mathbf{N}$ balance: there is also an increase in resting energy expenditure which may be proportionally less than the increase in $\mathrm{N}$ excretion. The relationship between energy intake and $\mathrm{N}$ balance is still evident in the seriously ill patient who is depleted and catabolic but the beneficial effect of increasing $N$ intake on $N$ balance is less. In a study of body composition measured by the isotope dilution technique in 204 patients who received total parenteral nutrition $(1 \cdot 28-2 \cdot 29 \mathrm{~g}$ protein and $206 \cdot 7-24 \mathrm{I} \cdot 7 \mathrm{~kJ} / \mathrm{kg}$ per $\mathrm{d}(49.6-58.0 \mathrm{kcal} / \mathrm{kg}$ per d)) for a total of 4447 patient days, Shizgal \& Forse (r 980 ) showed that the body cell mass of the normally nourished patient changed little although there was an increase in body fat. By contrast, in the depleted patient there was a significant improvement in the body cell mass without any 
significant change in body fat. No difference was detected in body cell mass between the different protein intakes and it was concluded that although a positive relationship may exist between $\mathrm{N}$ intake and balance at intakes of less than $1.28 \mathrm{~g}$ protein $/ \mathrm{kg}$ per $\mathrm{d}$, it is not evident in the hypercatabolic patient at higher intakes. These authors, in agreement with Long et al. (1974, 1976), also showed that carbohydrate energy is more effective than fat energy in promoting $\mathrm{N}$ balance and restoring body cell mass. Where the non-protein energy was supplied wholly by glucose, the body cell mass was maintained with a daily infusion of $150 \mathrm{~kJ} / \mathrm{kg}\left(3^{6}\right.$ $\mathrm{kcal} / \mathrm{kg}$ ), whereas when lipids supplied the non-protein energy an intake of 230 $\mathrm{kJ} / \mathrm{kg}(55 \mathrm{kcal} / \mathrm{kg})$ was required for $\mathrm{N}$ equilibrium. Further evidence of a lack of effect on $\mathrm{N}$ balance by increasing protein intakes from high levels comes from the work of Wolfe et al. (1983) who studied protein and urea kinetics in burns patients at daily protein intakes of 1.4 and $2.2 \mathrm{~g} / \mathrm{kg}$. Although the absolute rates of protein synthesis and catabolism were increased by the higher intake, the balance between them was not affected.

The patient exposed to the catabolic stress of injury or sepsis is therefore less capable of responding to high intakes of protein than the depleted or normal patient. The hypothesis elaborated by Elwyn ( 1980 ) would appear to hold true for the depleted and normally nourished individual in that positive $\mathrm{N}$ balance and an increase in body cell mass can be achieved by either an elevation of protein intake or by an increase in energy intake provided that the minimal requirements of each substrate are satisfied. This has particular relevance to the tissue component which it is intended to replenish. The composition of weight gain from excessive increases in energy intake is approximately two-thirds fat and one-third body cell mass, and it is likely that cell mass is increased predominantly to support the increase in fat (Keys et al. 1950; Calloway \& Spector, 1954; Kinney, 1978). The composition of weight loss in starvation and during hypercatabolism is approximately two-thirds body cell mass and one-third fat so that restoration of the major part of the body cell mass is unlikely to be affected by changes in energy intake but will require high levels of $\mathrm{N}$ intake and it is in conditions such as these that the optimum energy: $\mathrm{N}$ value may be low, in the region of $625 \mathrm{~kJ}: \mathrm{I} \mathrm{g} \mathrm{N}$ ( 150 $\mathrm{kcal}$ : $\mathrm{g} \mathrm{N}$ ). There is, therefore, no ideal ratio of energy: $\mathrm{N}$ which will be suitable for all clinical states and rather than rely on a fixed ratio each should be varied independently to suit the situation of the patient, taking into account nutritional state, metabolic state, the extent of physical activity and the capacity of the patient to metabolize effectively the administered nutrients.

\section{REFERENCES}

Abumrad, N. N., Rabin, D., Wise, K. L. \& Lacy, W. W. (1982). Metabolism 31, 463.

Askanazi, J., Carpentier, Y. A., Michelsen, C. B., Elwyn, D. H., Fürst, P., Kantrowitz, L. R., Gump, F. E. \& Kinney, J. M. (1980). Ann. Surg. 192, 78.

Askanazi, J., Fürst, P., Micheisen, C. B., Elwyn, D. H., Vinnars, E., Gump, F. E., Stinchfield, F. E. \& Kinney, J. M. (1980). Ann. Surg. 191, 465 .

Blackburn, G. L., Flatt, J. P., Clowes, H. A. \& O'Donnell, T. F. (1973). Am. F. Surg. 125, 447. 
Bozzetti, F., Terno, G., Baticci, F., Pupa, A., Bonalumi, M., Sequeira, C., Del Vecchio, M., Camerini, E., Bombardieri, E. \& Emanuelli, H. (1980). Surg. Gynaec. Obstet. 150, 491.

Burger, U., Wolf, H. \& Bauer, M. (1978). Infusiontherapie 5, 254.

Calloway, D. H. \& Spector, H. (1954). Am. J. clin. Nutr. 2, 405.

Elia, M., Ilic, V., Bacon, S., Williamson, D. H. \& Smith, R. (1980). Clin. Sci. 58, 309.

Elwyn, D. H. (1980). Critical Care Med. 8, 9-20.

Elwyn, D. H., Gump, F. E., Munro, H. N., Iles, M. \& Kinney, J. M. (1979). Am. J. clin. Nutr. 32, 1597.

Fürst, P., Elwyn, D. H., Askanazi, J. \& Kinney, J. M. (I982). In Clinical Nutrition '81, p. 10 [R. I. C. Wesdorp and P. B. Soeters, editors]. Edinburgh and London: Clinical Nutrition.

Keys, A., Brozek, J. \& Hemschel, A. (1950). Human Starvation. Minneapolis: University of Minnesota.

Kingsland, P. A., Kingsworth, A., Royle, G. T., Kettlewell, M. G. W. \& Ross, B. D. (1981). Br. J. Surg. 68, 234.

Kinney, J. M. (1978). In Advances in Parenteral Nutrition, p. 51 I [I. D. A. Johnston, editor]. Lancaster: MTP Press.

Kinney, J. M. (1980). In Practical Nutritional Support, p. 33 [S. J. Karran and K. G. M. M. Alberti, editors]. Bath: Pitman.

Long, C. L., Corsby, F., Geiger, J. W. \& Kinney, J. M. (1976). Am. F. clin. Nutr. 29, 380.

Long, J. M., Wilmore, D. W., Mason, A. D. \& Pruitt, B. A. (1974). Surg. Forum 25, 61.

Miller, J. D. B., Broom. J. \& Smith, G. (1983). Clin. Nutr. r, 237.

Moore, F. D. (1959). Metabolic Care of the Surgical Patient. Philadelphia: Saunders.

Mosebache, K, O., Stoeckel, H., Caspari, R., Muller, R., Schulte, J., Lippoldt, R. \& Prahl, M. ( 980 ). F. Parent. Enteral Nutr. 4, 346.

Mullen, J. L., Buzby, G. P., Matthews, D. C., Smale, B. D. \& Rosato, E. F. (1980). Ann. Surg. I92, 604.

Munro, H. N. (1964). In Mammalian Protein Metabolism, p. 38 I [H. N. Munro and J. B. Allinson, editors]. New York: Academic Press.

Peters, C. (1980). Surg. Gynaec. Obstet. $151,1$.

Reilly, J., Ryan, J. A., Strole, W. \& Fischer, J. E. (1976). Am. F. Surg. x31, 192.

Roth, E., Furnovics, J., Muhlbacher, F., Schemper, M., Mauritz, W., Sporn, P. \& Fritsch, A. (1982). Clin. Nutr. 1, 25.

Shizgal, H. M. \& Forse, R. A. (1980). Ann. Surg. 192, 561 .

Vinnars, E., Bergström, J. \& Fürst, P. (1975). Ann. Surg. 163, 665.

Vinnars, E., Holstrom, B., Schildt, B., Odeback, A. C. \& Fürst, P. (1983). Clin. Nutr. (In the Press.)

Wolfe, R. R., Goodenough, R. D., Burke, J. F. \& Wolfe, M. H. (1983). Ann. Surg. 197, I63. 